\title{
Review of the Interactive Writing Lesson Provided for Turkish Hearing-Impaired University Students
}

\author{
Guzin Karasu ${ }^{1, *}$ \\ ${ }^{1}$ School for the Handicapped, Anadolu University, Eskisehir, Turkey \\ *Correspondence: School for the Handicapped, Anadolu University, Eskisehir, Turkey. Tel: 90-222-335-0580-4912. \\ E-mail: guzinkarasu@anadolu.edu.tr
}

The study was supported by the Scientific Research Committee of Anadolu University with project number $1505 E 440$ and completed on 3rd of June 2017.

Received: November 13, 2018

Accepted: December 10, 2018 Online Published: December 17, 2018

doi:10.5430/wje.v8n6p116

URL: https://doi.org/10.5430/wje.v8n6p116

\begin{abstract}
When the literature about the writing expression of hearing-impaired students is reviewed, it is seen that there are studies in which the effectiveness of several approaches and the writing process are analysed, assessment and evaluation aspects are considered and comparisons are made with the level of skills of non-impaired peers. On the other hand, there is a need for researches regarding the method of implementation of writing lessons. In this study, it is explained how the pre-writing stage for the writing of a text is performed with hearing-impaired students through Interactive Writing. The study, based on the action research method, was conducted during the Fall term of the 2015-2016 academic year, at the Integrated School for the Handicapped of Anadolu University, located in Eskisehir province of Turkey. Participants of the study were seven hearing-impaired second-year students enrolled to the Computer Operating department. During the study, nine lessons were made based on the principles and components of the Balanced Literacy Instruction Approach (BLIA). Among the nine lessons, four of them were performed with interactive writing. When the language skill levels of the hearing-impaired students group of the study was considered, Interactive Writing was determined to be the most effective writing component for the group. However, the most effective writing component can be different for another hearing-impaired student group. Writing levels of the students, the types and amount of support they need and their level of knowledge about the text to be written were decisive in the determination of writing components.
\end{abstract}

Keywords: Turkish hearing-impaired college students, BLIA components, interactive writing, pre-writing

\section{Introduction}

Students pass through a set of stages during the improvement of writing skills. While they are more dependent on their instructors at the beginning of this process, they gradually improve their writing skills with the instructors' acting as a model and guidance (Tompkins, 2007). The objective of writing studies should ensure that students become able to write texts independently in the topics they define themselves, thanks to suitable guidance and the skills gain. The process of writing a text starts with planning and pre-writing before actual writing and continues with the writing, reviewing and editing of a draft. The process comes to an end when the written text is published in various environments (Richards \& Renandya, 2008; Tompkins, 1997; Tompkins, 2000). During the writing of texts, the manner of implementation and duration of the abovementioned stages vary. This variety is related to the level of support needed by students. As an example, in a class consisting of hearing-impaired students, drafting can be implemented through intensive action of the instructor as a model, with the participation of the whole class, while in another group of hearing-impaired students, drafts can be written by students individually, after the pre-writing stage is completed. The level of support needed by hearing-impaired students is related to their language skill levels (Schirmer, 2000).

Hearing-impaired students experience limitations in the improvement of language skills as a result of their impairment, which in turn negatively affect both their level of academic achievement and daily and private life. For this reason, the 
literacy approach preferred to be implemented for the improvement of hearing-impaired students' language skills is important.

\subsection{Balanced Literacy Instruction Approach}

Several researches reveal that the Balanced Literacy Instruction Approach (BLIA), used as one of the approaches in improving language skills of both hearing-impaired and non-impaired students, may provide positive results (Karasu, Girgin, Uzuner \& Kaya, 2012; Uzuner, 2007; Karasu, Girgin, Uzuner \& Kaya, 2016; Kaya, 2012; Pressley et al., 2002). Lessons performed with the BLIA properly support students in each stage and language level they are in, for the improvement of writing and reading skills (Schirmer, 2000; Tompkins, 2007). The objective of the activities and strategies applied is to improve students' skills and bring a sufficient level of literacy. Improvement of writing skill in the BLIA is achieved with the following components: a) Model Based/Shared Writing, b) Interactive Writing, c) Guided Writing and d) Independent Writing. In some studies, Model Based Writing and Shared Writing are specified as separate stages (Tompkins, 2007).

Through the process from Model Based/Shared Writing to Independent Writing, it is aimed to improve the writing skill of students and decrease their level of dependence on the instructor (Asselin, 1999; Pressley et al., 2005; Tompkins, 2007). The first three stages are seen as steps to reach the objective of becoming an independent writer. During this process, students are supported in line with their specific needs and levels. In each stage, writers of the texts (writing by the instructor who is acting as the model, joint writing by the instructor and the student, or individual writing by the student) and the strategies to be used are determined in consideration of the properties of students. As is known, texts are completely written by the instructor in Model Based/Shared Writing, while in Interactive Writing and later stages, the responsibility assumed by students in text writing increases in parallel with the improvement of their knowledge and skill of writing. In Guided Writing, the instructor puts emphasis on the stages and properties of the writing process and the introduction of strategies and skills. In Independent Writing, on the other hand, the text writing process is completely carried out by students (Tompkins, 2007). Since a lesson performed with Interactive Writing is explained in this paper, this writing component will be defined in detail.

\subsection{Interactive Writing}

Interactive Writing is implemented to improve the literacy skills of students who are new in literacy education and/or experience difficulties in the improvement of their literacy skills. In Interactive Writing, the lecturer provides support and education to students at the points and in the levels they exactly need, in order to contribute to their improvement (Dostal \& Gabriel, 2015). Its roots can be found in the Language Experience Approach (Button, Johnson \& Furgerson, 1996). In this component of writing lessons, topics of writing are selected jointly by the instructor and students. Writing of the text is also performed through the cooperation of the lecturer and students and the whole class develops ideas in creating the text. Students go to the board one by one to write letters, words or sentences (McCarrier, Fountas \& Pinnell, 2000). While the instructor helps students to write letters, words and punctuation marks, he or she also tries to improve the knowledge of students in spelling rules. While the text is created through questions and the answers given to them, the board marker is alternately held by the instructor and students. The instructor guides students with questions such as "From which point should I start writing?", "What should I write now", "What should be the next word?", "What should be put at the end of the word/sentence" and "Is the sentence correct?" and he or she intensively acts as a model for students in the process (Button et al., 1996; Dostal \& Gabriel, 2015).

In lessons performed with Interactive Writing, both the writing and reading experience and skills are given, and instant feedback is provided to students. After the text is written with Interactive Writing, they are used as reading texts for being read in the classroom (Button et al., 1996; Dostal \& Gabriel, 2015). In this way, the process supports both reading and writing skills. In addition, repetitions made through the reading of texts help the integration of text infrastructure properties including the development of text structure, reminding of characters and the course of the incidents in the story, learning of different words and the improvement of grammar skills (Button et al., 1996; Dostal \& Gabriel, 2015; Kronenberg, 2014). The technique can be used during the pre-writing and drafting stages of the lesson as well.

\subsection{Researches on Writing and Interactive Writing of Hearing-impaired Individuals}

When the texts written by hearing-impaired students are reviewed, it is seen that they make mistakes regarding affixes, create too short sentences and develop a very limited number of complex sentences. Their vocabulary is at much lower level when compared to non-impaired peers. They experience difficulties in the correct use of pronouns, adjectives, the passive voice, conditional sentences and conjunctions (Rose, Mc Anally \& Qigley, 2004). Hearing-impaired students generally need to improve their writing skills to a higher level in areas such as making introductions to a topic, organizing thoughts, planning and defining the group of readers (Antia, Reed \& Kreimeyer, 2005; Yoshinaga-Itano \& 
Downey, 1996). They are known to the benefit from lessons structured in line with their levels and needs in enriching syntax and text content, although they can rarely reach the same level with their non-impaired peers (Antia et al., 2005).

Any research conducted by use of Interactive Writing cannot be found in Turkey for hearing-impaired students who are in need of intensive support to improve their writing skills. Studies done with hearing-impaired students are seen to be rare in other countries as well. The literature provides studies conducted by Wolbers together with several other researchers, by use of Interactive Writing and Strategic and Interactive Writing Instruction (SIWI). Wolbers (2007) reviewed the lessons she performed with severe-degree hearing-impaired primary school students by use of Interactive Writing. In the research, lessons were performed in line with the needs of hearing-impaired students who also had previously taken Interactive Writing lessons. After twent one days of research, results of the preliminary and final tests were performed and assessments were done during the writing and reading lessons, which revealed that the students became able to write in accordance with the specified text types, use a language suitable for the context and show significant improvement in reviewing, correction and word recognition.

Wolbers, Dostal \& Bowers (2012) analysed the improvement obtained on the writing expression skills of 29 profound-degree hearing-impaired middle school students from the point of the length of writing, making complex sentences, sentence awareness and functions of words during the lessons performed with SIWI. Certain analyses were made in the research in order to determine the gains of hearing-impaired students with different levels of language in literacy lessons. Notwithstanding the level of gain of students, they were determined to have statistically significant gains in terms of length of writing, sentence complexity and sentence awareness. In another study conducted by Dostal \& Wolbers (2014), the effect of SIWI on the development of writing in the native language and the expressive language dimension of sign language were examined. As a result of the study, it was determined that there was no negative impact on the written expression skills of students who focussed on sign language, which does not have a written format. On the other hand, students who focussed on sign language and writing in the native language had significant gains in both language development and written expression skills.

Wolbers et al. (2015) conducted a study on severe-degree hearing-impaired students with SIWI. In the mentioned study, effects of SIWI on the skills of students in writing stories, reports and persuasive letters were examined, and it was seen that there was a meaningful relationship between the implementation of SIWI and the improvements obtained in the general writing performances of students. The researchers suggest SIWI as a promising tool for hearing-impaired primary school students and they call for further studies for further improvement and construction of the technique.

In the study conducted by Williams (2011), the effectiveness of Interactive Writing practices was aimed to be defined. For the study, writing lessons were performed by being adapted to the level of a young age group of hearing-impaired students who recently started to receive writing education. Forty five writing lessons performed by use of Interactive Writing during the one year term of the study were then analysed through video analyses. Findings of the research revealed the actual potential of Interactive Writing in supporting the early improvement of writing skills for hearing-impaired children.

In the literature, all studies conducted on hearing-impaired students by use of Interactive Writing support the effectiveness of this writing component of BLIA. However, it is noted that further studies are needed about Interactive Writing, which positively affects the general writing performance (Wolbers et al., 2015). Besides, existing studies in Turkey on the writing skills of hearing-impaired students are seen to be about the examination of the effectiveness of different educational setups and methods, description of writing levels, development of measurement tools and determination of the types of mistakes (Erdiken, 1989; Erdiken, 1996; Girgin \& Karasu, 2007; Karasu \& Girgin, 2007; Tuncay, 1980), and researches about "how" the writing lessons can be performed are needed (Karasu, 2014; Yuknis, 2014). The overall objective of this study is the examination of writing expression lessons planned for the effective improvement of hearing-impaired university students' written expression skills. For this purposes, the paper addresses the implementation of Interactive Writing during the pre-writing/planning stages of the writing process.

\section{Method}

This is a teachers' research done through action research. In action researches, relevant data are systematically collected in order to obtain information about a practice from an individual or a group subjected to an implementation in a certain setup, reveal problems related to implementation or determine and solve an existing problem (Fraenkel \& Wallen, 2003; Yıldırım \& Simsek, 2006). Action researches conducted by teachers increase the level of learning of students and contribute to the professional improvement of teachers the same time (Creswell, 2005). 


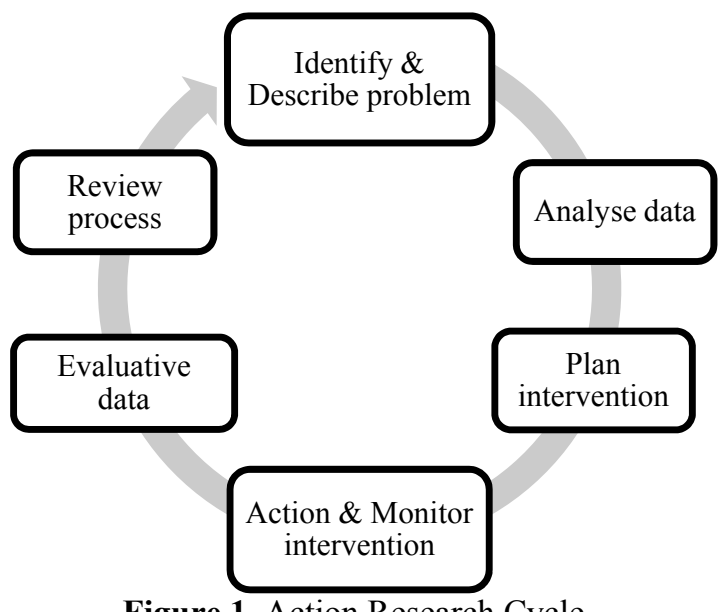

Figure 1. Action Research Cycle

In the study, during which both qualitative and quantitative data were collected, the problem was determined, the literature was searched and the research process was defined. The collected data were analysed and interpreted both during and at the end of the research and certain action plans were developed (Fraenkel \& Wallen, 2003; Johnson, 2002). The process was implemented cyclically, instead of a linear approach (Figure 1). The study was conducted through action research, since the targets set by the institution in which the research was done would be met in this way.

\subsection{Environment}

The research was realized at the Integrated School for the Handicapped, the only institution providing university education to hearing-impaired young people in Turkey. The school has four different education programs, namely Graphic Arts, Ceramic Arts, Computer Operator Training and Architectural Drafting. The lessons are given in language classrooms and laboratories and workshops related to the study fields of the students.

The data of this research were collected in the language classroom number 214 of the Vocational High School. Sound insulation was ensured in the classroom by use of curtains, carpets and insulation materials placed on the ceiling and walls. The classroom had a smart board, a tripod portable writing board, a library, a teacher's table, a rectangular table and chairs for group and individual works and armchairs for group language lessons. The writing environment was shaped based on the properties of the lesson performed. In group language lessons, the students sat on armchairs in a U-arrangement in front of the smart board or portable writing board. The walls were used as signboards on which the products of the lesson were displayed.

\subsection{Participants}

2.2.1 Students. Four profound-degree and three severe-degree sensory-neural hearing-impaired students who were enrolled to the final year of the Computer Operator Training Program during the 2015-2016 academic year participated in the research. One of the severe-degree hearing-impaired students was also orthopedically handicapped. Other properties defining the language levels of the hearing-impaired participants are given in Table 1 . The students voluntarily took part in the study. They were all informed on the research and their written consents were obtained.

Table 1. Properties of the Students

\begin{tabular}{|c|c|c|c|c|c|c|}
\hline Student & $\begin{array}{c}\text { Age } \\
\text { Gender }\end{array}$ & $\begin{array}{c}\text { Degree of hearing } \\
\text { loss } \\
\text { (better hearing ear) }\end{array}$ & $\begin{array}{c}\text { Age of onset of } \\
\text { hearing } \\
\text { impairment }\end{array}$ & $\begin{array}{c}\text { Age of } \\
\text { diagnosis }\end{array}$ & $\begin{array}{c}\text { Age of onset } \\
\text { of hearing } \\
\text { aid }\end{array}$ & $\begin{array}{c}\text { Secondary education } \\
\text { environment }\end{array}$ \\
\hline Hakan & $23 / \mathrm{M}$ & $113 \mathrm{~dB} \mathrm{HL}$ & Congenital & 1 & 2 & Vocational High School \\
\hline Busra & $22 / \mathrm{F}$ & $101 \mathrm{~dB} \mathrm{HL}$ & 0.10 & 0.10 & 2 & (Meanstreaming) \\
\hline Zeynep & $25 / \mathrm{F}$ & dB HL & Congenital & 1 & 14 & \\
\hline Fevzi & 19/M & $110 \mathrm{~dB} H \mathrm{HL}$ & Congenital & 2 & 19 & Vocational High School \\
\hline Ilker & $22 / \mathrm{M}$ & $118 \mathrm{~dB} H L$ & Congenital & 6 & - & for Hearing Impairments \\
\hline Hasan & $25 / \mathrm{M}$ & $\mathrm{dB} H \mathrm{H}$ & Congenital & 5 & 12 & \\
\hline Yahya & $23 / \mathrm{M}$ & dB HL & Congenital & 11 & 16 & \\
\hline
\end{tabular}


Four of the students were determined not to have significant problems in receptive and expressive language skills, while they had certain limitations. On the other hand, because of the receptive and expressive language problems experiences by the remaining three students, important notions, questions and ideas were written on the board and/or supported in sign language in order to help them in following the subjects during the lessons.

High school graduate hearing-impaired students from all provinces of Turkey receive education at the School for Handicapped, where the study was conducted. When the properties of the hearing-impaired students in terms of their language levels and the accessibility of the school for different provinces/regions are considered, it is seen that the school has students using different communication methods at various language levels. For this reason, communication with the students during the lessons was done through Total Communication, in which verbal communication, writing, visual materials and sign language are used all together.

The preliminary test applied to determine the level of the students' writing skills, five of the seven participants were seen to write texts in accordance with the instructions given, while the text contents of other two students were seen to be unsuitable. All students were observed to develop limited text contents and be in need of support for enrichment. Two of the participants gave place to the introduction, body and conclusion parts in their texts. Besides, two of them were seen to use titles while three participants did not use titles at all, and two students used titles for one of the texts they wrote. Four of the students were understood to be in need of intensive support for the improvement of syntax and had very limited vocabulary when compared with their peers. In addition, the same students made mistakes of noun-cases, noun phrases and possessive and genitive suffixes, and they preferred to construct only short sentences.

\subsubsection{Research Team}

The research team consisted of a supervisor, a researcher/implementer and a researcher. The team members were also members of the validity and reliability committee of the research. The supervisor lectures at undergraduate, graduate and postgraduate levels for hearing-impaired students, in addition to acting as an executive and supervisor of theses and projects conducted with qualitative research methods. The researcher/implementer, who collected the research data and, is able to use the sign language at a certain level and lectures in several courses of the School organized under the "Language Courses" title, with an experience of four projects and three doctorate theses with the action research method and studies presented at national and international conventions and published in scientific journals. Last member of the research team, the researcher, gives language lessons at the School, and took part in the implementation and inter-evaluator reliability and validity studies of the research. The whole research team had at least 20 years of professional experience in the education of hearing-impaired students as of the date of the research.

\subsection{Data Collection Techniques and Analysis}

The data of the research, in which the qualitative and quantitative data collection methods and techniques were used, consisted of the video recordings of the lessons (Writing and Speaking Skills Course III: 33 hours and 4 minutes; Individual Language Support Course III: 18 hours and 48 minutes), voice records and reports of the trustworthiness committee (10 pieces), lesson plan and assessments (11 pieces), students' files, journals and notebooks; students' audiograms; documents related to the students' primary and middle school education; and preliminary test/final test results. Data collection and analysing were carried out simultaneously (Creswell, 2005). Based on the objective of the research, the data were analysed systematically, cyclically and reflectively, in accordance with the decisions made at the meeting of the research team.

A criterion-references test was applied for the research in order to determine the level of skills of the students in writing of stories, informative texts and newspaper reports. In the first three of the five questions asked, the students were asked to write a newspaper report, informative text and story without giving a visual hint. The instructions used for the exam were "1. Please write a newspaper report; 2. Please write a news report about a topic such as technology, arts or health; and 3. Please write a story for the newspaper". In the last two questions, some news reports with informative photos were given to the students and they were asked to tell the news they read with their own sentences and express their feelings and thoughts.

For the validity study, expert opinion of the research team was obtained about the suitability of the questions from the point of the ages and areas of interest of the students, in addition to the clearness of the questions and their fitness to the objective of the research, upon which necessary adjustments were made. The Written Expression Skills Assessment Tool developed by Erdiken (1998) was used for the assessment of the students' writing skills. The tool assesses the texts from the point of format (0-30 points), content (0-20 points), vocabulary (0-20 points), grammar (0-20 points) and orthographic rules/punctuation (0-5 points).

Preliminary and final test data of the research were collected on $5^{\text {th }}$ of October 2015 and $12^{\text {th }}$ of January 2016 
respectively. The implementation validity coefficient was calculated with the Observed Implementer Behaviour/Planned Implementer Behaviour X 100 formula. In the implementation reliability study revealed a consensus of $94.5 \%$. Regarding the inter-evaluator reliability results, consensus of $84.8 \%$ and $71.9 \%$ were obtained for the preliminary and final tests respectively.

\section{Findings and Discussion}

In the findings section, the research question will be answered after the research process is explained in brief.

\subsection{Research Process}

This paper includes the analysis of a certain part of data collected during the implementation process of the research which consisted of the preparation and implementation processes. The implementation data were collected between October of 2015 and January of 2016, during the Writing and Speaking Skills III (WSS III) and Individual Language Support III (ILS III) lessons. Activities for improving the writing skills of the students were largely performed during the WSS III lesson. On the other hand, other vocational courses of the school academic program were supported, preliminary and final test data were collected and individual writing editing activities were performed during the ILS III lesson. During the course of the project, data collection was made five class hours a week, consisting of two 45 minute ILS lessons every Monday and three 45 minute WSS III lessons every Tuesday.

In total, nine texts were written in the project, including messages, newspaper reports and informative texts. The students" needs regarding the "text types" used in their vocational education were decisive in determining the types of texts to be written. As a result of the assessments made, it was decided to start the first lesson with Interactive Writing, in which the students are intensively supported and the instructor acts as a model and provides immediate feedback (the Trustworthiness Committee Report dated $21^{\text {st }}$ of October 2015). With the decisions made throughout the process, improvement of the students was taken into consideration and writing components of other texts were determined. Four of the texts were written with Interactive Writing, while the Guided Writing and Independent Writing components were applied for three and two of the texts respectively. In this study, the pre-writing stage of a biography text written with Interactive Writing will be explained.

\subsection{Pre-Writing Process in Interactive Writing}

The lesson explained in this paper was specifically selected, since it presented the typical properties of the Interactive Writing component performed with the students. The text was planned under the general title of "Sightseeing News". The topic was decided jointly with the students, during the selection of a news topic for the school newspaper called Entegre Haber at the beginning of the academic term. The question "In which topic would you like to write in the school newspaper?" was asked to the students and "Sightseeing News" was found to be the most preferred topic in the list. Afterwards, important places to visit in the city were listed and it was decided to visit the "Yilmaz Buyukersen Wax Museum" as a result of the vote taken. Determination of the lesson subject by the students offered them the opportunity to select and embrace the subject, and their level of motivation towards the subject increased as a result (Pearson et al. 2007; Pressley et al.. 2002). Prof. Dr. Yilmaz Buyukersen, whose biography was written during the lesson, was born and grew up in Eskisehir, the city in which Anadolu University is located. Buyukersen was a former rector of the university and he has been the mayor of the city for long years. The broad vision and foresight of Buyukersen helped the city to become a modern centre of arts, science and culture.

Under the selected topic, three texts were written with titles "Yilmaz Buyukersen Was Museum", "The Life of Yilmaz Buyukersen" and "The Museum Website". Preparations for the visit and writing of the texts were completed between $6^{\text {th }}$ of October and $15^{\text {th }}$ of December 2015. Writing of the text titled "The Life of Yilmaz Buyukersen" was planned the week before the lesson in which the text would be written (Lesson Assessment dated 17 $7^{\text {th }}$ of November 2015). Afterwards, the text was written in three class hours (45 minutes x 3 ) on $24^{\text {th }}$ of November 2015, with the participation of six students.

The pre-writing stage of writing was performed with the listing activity. The researcher observed the content generation and enriching limitations of the students firstly based on the preliminary test results and then in the texts written by them, and the text content was planned to be generated by preparing a list (preliminary test results and Lesson Assessments dated 6-1 $17^{\text {th }}$ of October 2015 and $18^{\text {th }}$ of November 2015). The list, which can be defined as a graphical organizer, was used to offer an alternative visual presentation of the information, organise the information and support permanence (Heilman, Blair \& Rupley, 1990). In their researches conducted with hearing-impaired students, Fox (1983) and Nagy, Anderson \& Herman (1987) state that graphical organisers help students to reorganise existing information and notions. In addition, according to Stahl, Jacobson, Davis and Davis (1989), providing 
preliminary information about the text to students by use of graphical organisers helps the process.

The list prepared during the pre-writing stage was written on the drawing paper placed on the tripod board. The empty spaces on the board were used for purposes such as for asking and answering questions, correcting mistakes and showing the correct spelling of words. During the writing of the text, the list was continuously kept on the board.

The implementation of the lesson will be narrated by use of the description technique. Lesson descriptions are given in italics, while the conversations are shown in quotes. Words and sentences decided to be included in the text are given bold and in italics. In order to avoid unnecessary repetitions, the whole process will not be narrated. Sections removed for this purpose are specified with triple dots (...).

3.2.1 Lesson Description. I started the lesson by reminding that we would write a text about the life of Yilmaz Buyukersen, and I wrote the subject on the board. I had given a research assignment on the subject to the students the week before. I wanted them to read very carefully the resources they brought to the classroom and underline the information they consider important (24 th of November 2015 / Video No 1: 8'34'). Meanwhile, I strolled among the students, checked the written and visual resources they had brought and asked them if there was any word which they didn't know the meaning. They asked the meanings of "mask", "donation" and "revenue". I explained the class the meanings of these words by writing definitions and examples on the board. The students noted the information on the board in their notebooks. We continued the lesson, after all students marked the parts they considered important in the resources they had brought.

Determination and underlining of important information in a text is an effective strategy in improving students' reading comprehension skills (Heilman et al., 1990; Searfoss and Readence; 1989). While they try to find the information they consider important, students read the text again and again and make effort to find out the meaning. During this activity, the researcher strolled among the students and supported them through observations and questions when they needed (Kronenberg, 2014; Wolbers, 2007).

Afterwards, we started listing important information about the life of Yilmaz Buyukersen. I verbally asked the students to tell the important information they specified about the life of Yilmaz Buyukersen. Nobody answered except Zeynep. Thus, I wrote my question on the board and wanted Zeynep to repeat her answer in sign language. Busra said "Ataturk mask". I wanted her to write on the board and she wrote (24 th of November 2015 / Video No 1: 23'10')

$\cdots$

I asked the whole class, "What other information have you read?". Zeynep said, "He went to England in 1996," and she wrote on the board. I asked to Ilker "What did he do there?" both verbally and by use of sign language. When I could not receive an answer, I asked the same question to Busra and she answered. I wanted Ilker to repeat the answer. He repeated what Busra said as "He went to England. He visited Was Museum". I asked "Where did he go?" and wrote on the board "Nereye? (Where?)" by underlining the interrogative particle. I made the direction sign and said "direction, going". Ilker said "to England". He said the affix correctly. At the same time, I showed the correct writing by Zeynep on the board. He read as "He went to England". I asked, "We said wax museum. How should we write?". He said, "Let's write he visited the wax museum". He corrected the affix mistake himself, wrote on the board and returned to his chair. I asked both verbally and by use of sign language, "Did he like the Ataturk sculpture?". They said "No". As a continuance of the previous sentence, I wrote on the board "He did not like the Ataturk sculpture".

During the lesson, various questions were asked to the students for purposes including directing the lesson, being sure whether the subject was understood and correcting mistakes. When the properties of the questions asked verbally or in written, supported in sign language, and the length of question sentences are reviewed, it was found out that the complexity of questions and the style of communication varied based on the language levels and communication skills of the students.

I asked, "Do you want to add anything?". Zeynep said, "He is a former rector of Anadolu University". I wanted her to write on the board. I asked the meaning of the word "rector". After considering the answers given by the students, I said "The person who directs the university, like a manager" verbally and by supporting in sign language. I preferred the term "manager", since I was sure that they knew its meaning. I wrote the definition on the board. The students noted the definition on their individual dictionaries.

Afterwards, I asked Hasan, "What else should we write about Yilmaz Buyukersen?". He answered, "The mayor". I said "Very good". I asked him to write on the board and he did it. Meanwhile, Zeynep said "He opened the first wax museum on $19^{\text {th }}$ of May 2013". I stated that Zeynep defined important information. I wrote what she said on the board. 
The level of language of Zeynep allowed her to write the sentence she said on the board without any mistake. Since I knew that she would be able to write and she previously contributed to the lesson by writing on the board, I wrote the sentence myself in order for the efficient use of time.

I wrote what we wrote on the list until then. I asked Fevzi, what he would like to add. What he said could not be understood. I read the part he underlined in the text as "He sculptured 160 famous persons". He explained in sign language. I wanted Fevzi to write the same on the board. He wrote by sight-reading. Then, he said who the famous persons were. I said that we could add them in the text later. I asked, "Is there any other information?". On the text he had, Fevzi showed that Buyuksersen made Ataturk Sculptures for Ankara, Eskisehir and some other cities, and he told what he understood in sign language. I asked, "Ankara, Eskisehir, Istanbul... Should we write all? What should we say?". Hakan said "Turkey". I wrote "Turkey" on the board, put an apostrophe to the end and wrote "Nerede (Where)?" by underlining the interrogative particle. I explained as "Being in" and supported in sign language. Hakan and Hasan said "In Turkey". Fevzi showed the letters " $d$ " and " $e$ " with his fingers. I added the "-de" affix and said "OK, good". I wrote in the list "In Turkey". "How should we continue the sentence?" I asked. Zeynep raised her hand, but I wanted another student to answer. When I could not receive an answer, I wrote the question "For which cities?" on the board. They listed the cities and I wrote on the board. By taking the city names in a circle, I said "Many cities". Afterwards, I asked "What did he do?" and support the question in sign language. Zeynep, Hakan and Busra said "Ataturk sculptures" together. I organized the sentence and wrote on the board "He made Ataturk Sculptures for many Turkish cities".

Then, on the text he had brought Fevzi showed the information that "The revenue of the museum will be spent for the education of girls and the handicapped". I asked, "What revenue means?" and wrote the question on the board. They knew the meaning and made the money sign with their hands, and I approved. "How should we write?" I asked. Fevzi said "money - girl - handicapped - to give" in sign language. I approved and wrote the sentence in the correct syntax as "The revenue of the museum will be given to girls and the handicapped". We talked about the fact that Buyukersen or the municipality would not receive the revenue, since it was a donation, and the importance of it. I added the term "Donating" in the list.

$\cdots$

I asked Hakan, "Do you want to say anything about Yilmaz Buyukersen and sculptures?". Hakan said that he had not read. He had not performed his task. When Ilker told some information about fine arts, I said and showed him that we had previously added that in the list. I wanted him to be more careful.

I asked Fevzi again and he said "He became an assistant professor in 1968." I wanted him to write on the board. While he was writing, Zeynep said "He became a professor in 1973". We combined the two sentences and the new sentence was written on the board jointly by the two students as "He became an assistant professor in 1968 and a professor in 1973". Busra asked the meaning of the term "assistant professor". I explained in written on the board. I told that the information about being an assistant professor or professor were related to the "academic life and education" by making a note. I made the students read the term "academic life" first as a group and then one by one.

I asked the whole class "Do you want to add any other information?". Fevzi talked, but what he said could not be understood. He showed information about the private life of Buyukersen on the paper he had. I wanted him to write in the list. Bu sight-reading, he wrote "married, there are 2 children, 2 grandchildren" on the board. I wrote along "Married with two children and two grandchildren". I explained that this was "private life" and noted as "private life" alongside.

The words and terms written by the students on the board were immediately corrected in accordance with Turkish language syntax rules and written on the board by the researcher. One of the reasons to prefer this method was the requirement to act as a model for the students. The other reason was related to the actual levels of the students, since all students except one were unable to structure meaningful sentences by use of the words written by Fevzi on the word in a telegraphic language. The researcher made decisions during the lesson and directed the lesson accordingly, based on the considerations made before and during the research about the language levels of the students (Wolbers et al., 2015).

I asked the students again if they had anything to add. They said that they did not. I said that the list was completed. We read the list aloud as the whole class (Video No II: 17'39'). I said "Let's put a title to our list. There are words and sentences. What should be the title of the list?". Hakan said "Yilmaz Buyukersen". I approved and added "There are words and sentences. How can we add these in the title?". I wrote words and sentences on the board. I pointed Hakan and said "Your friend said Yilmaz Buyukersen". Hasan said "Words and Sentencer Related Yilmaz Buyukersen". I wrote "Kimle (to whom)" on the board and underlined the affix-le. Hasan said "to Buyukersen". I wrote the title of 
the list as "Important Words and Sentences Related to Yilmaz Buyukersen" on the board. Afterwards, they noted the list on the board in their notebooks. While other students continued writing, I asked students who finished the task earlier to read aloud. I corrected faulty readings.

The words and sentences written in the list were "Ataturk mask", "He went to England in 1996", "He visited the wax museum. He did not like the Ataturk sculpture", "He likes fine arts (painting, glass works, sculpturing, music, theatre, ceramics, graphics...), "Anadolu University", "Former rector", "Mayor", "He opened the first wax museum on $19^{\text {th }}$ of May 2013", "He made the sculptures of 160 famous persons", "He made Ataturk sculptures for many Turkish cities", "The revenue of the museum will be given to girls and the handicapped", "He became an assistant professor in 1968 and a professor in 1973", "He took the photos of famous guests visiting Eskisehir", "Married", "Has two children", "Two grandchildren", "Married with two children and two grandchildren". The list consisted of twelve sentences and five words/word groups. On the lesson plan, the researcher initially planned to include important notions/words in the list. However, it was decided during the lesson that a list consisting only of words would be challenging for the students and a list mainly consisting of sentences was prepared (the Lesson Assessment dated $24^{\text {th }}$ of November 2015). The list created reflects the language levels of the students in the class. A list that would be created with other students having different properties should be expected to reflect a different level of language.

Implementations with the BLIA require equal presentation of all language components in the daily and weekly lesson plans (Schirmer, 2000; Tompkins, 2000). The researcher used strategies and techniques towards the improvement of aloud and silent reading, writing, speaking and listening skills while performing the pre-writing stage of the text writing process (Asselin, 1999; Pressley et al. 2005; Tompkins, 2000).

\section{Yılmaz Buyukersen's Life}

Y1lmaz Buyukersen had a successful life. In this article we will talk about his academic, private, political life and love of fine arts.

Y1lmaz Buyukersen is the former rector of Anadolu University. He became associate professor in 1968 and professor in 1973. He made Anadolu University a very successful one and he founded the faculty of Open Education.

He was elected as the mayor of Eskisehir Municipality in 1999 and still continues to perform his duties.

He loves fine arts. In 1996 he went to England and he visited a wax museum. He didn't liked Ataturk's wax statue in that museum because Ataturk's face was different. Then Buyukersen received Ataturk's mask from Anitkabir. And he built a statue of Ataturk for many cities.

Y1lmaz Buyukersen made the statue of 160 different celebrities. He took photographs of famous visitors who came to Eskisehir to make their sculptures. He opened Turkey's first wax museum on May 19, 2013. Museum income is given to girls and disabled people.

Y1lmaz Buyukersen is married, has 2 children and 2 grandchildren.

Figure 2. The Text Written with Interactive Writing

The text seen in Figure 2 was written by use of the list created. Text writing was again performed with Interactive Writing. The text written on a drawing paper was published by being hanged on the classroom wall. This way, the writing process of the text was completed by sharing it with other students and lecturers who use the same classroom. In the pre-writing stage of the writing lesson, the researcher and the students jointly created a list in cooperation. The 
list was completed by items added by the researcher or the students themselves (Dostal \& Gabriel, 2015; McCarrier et al., 2000). During the writing of the text, the researcher provided information about the meanings and correct spellings of words and sentences, text format and grammar rules, and made corrections when mistakes were made by the students (Button et al., 1996; McCarrier et al., 2000; Tompkins, 2000). The students were observed to feel themselves relaxed and have high level of motivation during the lesson (Kronenberg, 2014; Williams, 2011; Wolbers, 2008). It is thought that this was thanks to the effectiveness of Interactive Writing as a writing component for this group of hearing-impaired students. The students could immediately receive the necessary support and feedback when they needed (Kronenberg, 2014; Luckner \& Cooke, 2010; Paul, 1998; Schirmer, 2000).

Pre-writing stage for the texts to be written with Interactive Writing or another writing component of the BLIA can be performed with several activities including the reading of stories, news reports, informative texts or poems, analysing single or a set of pictures and sightseeing (Asselin, 1999; McCarrier et al., 2000; Pressley et al., 2005; Tompkins, 2000). The researcher decided to perform the pre-writing stage of the text by generating a list, because of the limitations of the students in written expression skills. The language level of the list reflects the language levels of the students who participated in the lesson. As mentioned before, if a list is generated with other hearing-impaired students having different levels of language, a list with a similar content, but different level of language should be expected to be generated.

In addition to listing, various strategies and techniques were used for the lesson. Question and answer and acting as a model were the two most used strategies (the Lesson Plan and Assessment dated $24^{\text {th }}$ of November 2015). The lecturer used the techniques of acting as a model by writing, ensuring that students act as models for each other and deciding to ask questions verbally or in written. Effort was made to apply the strategies and techniques in a way that would increase the level of awareness of the students in a timely and suitable manner. In this way, it was aimed to increase the metacognitive awareness of the students (Joseph, 2006). Metacognitive implementation of strategies and techniques is a metacognitive strategy applied for improving the skills of students who experience limitation in terms of reading and writing (Joseph, 2006, Scott-Weich \& Yaden, 2017).

Again in the pre-writing stage, the researcher asked questions to all students about what can be written in the text, in order to obtain contribution of each student to the text. Opinions, information and answers of the students were shared with the class and the sentences to be written were decided jointly (Button et al., 1996; McCarrier et al., 2000). It is thought that this method of text writing positively affected both persistence and the motivation levels of the students. In addition, the lecturer made decisions during the lesson regarding the students who would answer the questions and add writings in the text individually or jointly writing with the lecturer. In these decisions, the number of previous contributions made by the students to the text, their language levels and the duration of the lesson were decisive.

In the text writing stage after the pre-writing stage was completed, the students were observed to have the tendency to copy the sentences or word groups as is to the text. Although the sentences in the list were jointly generated by the researchers and students through Interactive Writing, the researcher suggested the class to express the content by the use of different sentences. However, this suggestion did not gain the acceptance of the students. The researcher needed to direct the students by asking question in order to ensure that new words and sentences were added in the text. This is explain to be caused by the limited language skills and writing experiences of the students, and the resulting anxiety of making mistakes.

It was determined that the implementation of the writing components of the BLIA in accordance with the principles of the approach had a positive effect on the improvement of writing skills (Asselin, 1999; Pressley et al. 2005; Tompkins, 2007). When the preliminary and final test result of the research were analysed, it was understood that the written expression skills of the students improved during the three months research process, even in a limited scope. Six of the students gave place to the introduction, body and conclusion parts in their all texts, and five of them put titles for all texts. When the contents of the texts were reviewed, it was seen that all six students created contents in line with the instructions given. The students were observed to make progress in terms of text structure and writing suitable contents. However, it must be noted that these information and skills need to be reinforced with repetitions in future lessons. Final test results revealed that the students' limitations in vocabulary, grammar and punctuation continued. This finding of the research is in parallel with the results obtained by Wolbers, Dostal \& Bowers (2012). Hearing-impaired students are known to need longer time and more repetitions for the improvement of these skills (Campra, 1994; Dostel \& Wolber, 2014; De La Paz et al. 2016; Paul, 1998; Schirmer, 2000; Williams, 2011; Wolber, 2007; Wolbers et al. 2015). When the final test results were analysed in general, it was determined that the improvement made by the students were in relation to their initial language levels and students with higher language levels made more progress.

Four of the nine texts written during the research were created with Interactive Writing, while the numbers of the texts 
created with Guided Writing and Independent Writing were three and two respectively. Students are more independent and they take more responsibility in Guided Writing and Independent Writing. Average age of the students who participated in the research was 22.7. In spite of their limitations in terms of reading comprehension and writing skills, they had a certain level of experience and personal roles assumed. Based on these considerations, while the lessons were performed in line with their language levels, attention was paid to offer an environment in which they could feel independent and take more responsibility to make them feel the adolescent/young person role and use their previous experiences. Lesson plans and the decisions made by the researcher during the lessons were effective in achieving these goals (Wolbers et al., 2015)

It was seen that Interactive Writing was more supportive when compared to other components for the hearing-impaired students who had the language levels explained in the study. However, the whole research was not conducted with Interactive Writing and it was aimed to gradually increase the level of responsibility taken by the students in writing texts. For this reason, Interactive Writing is thought to indirectly improve the writing skills of the students. The findings of this research are seen to be in parallel with the findings of the studies conducted by Dostel \& Wolber (2014), Williams (2011) Wolber (2007), and Wolbers et al. (2015) with hearing-impaired students by use of Interactive Writing, from the point of the opportunities provided by Interactive Writing in structuring the lessons in accordance with the needs of students and ensuring that they write texts suitable for the instructed text types and use a language in line with the context.

Language levels and communication methods of the students who participated in the research were varying. The group consisted of students who used only the sign language, only the auditory verbal method and/or the sign language and the auditory verbal method together. This was a general case for all classes of the school. In the School where the research was conducted, hearing-impaired high school graduate students from all provinces of Turkey with different educational environment origins receive education. The means of access the students had during their primary and middle school education regarding suitable educational environments, special education teachers, special education support services and supports for the improvement of language skills are seen as the main reason of the variety observed in the group in terms of language levels and communication methods.

Most of the studies in the literature about the improvement of writing skills are experimental quasi-experimental studies analysing the cause and effect relations between variables. Said studies have laid the groundwork for the examination of the process by presenting the interaction between variables. The fact that action researches answer the question "How?" was a decisive factor in determining the methodology for this study (Mills, 2003). Besides, because of the differences in language levels of hearing-impaired individuals, experimental studies face problems regarding the equivalence of the number of subjects and analysing of the data, which was another reason to organize the study as an action research. In addition, being conducted as a teachers' research, the study also supported the professional progress of the researchers thanks to the trustworthiness meetings and detailed assessments made with experts in the field.

\section{Conclusion and Suggestions}

Improvement of literacy skills requires long period of time and an effective education. Lessons performed with hearing-impaired students, who experience difficulties in the improvement of literacy because of their impairments, should be structured in line with the language levels and needs of the students. Writing components of the BLIA support the education of students with different levels of writing skills. In this study, which was conducted with hearing-impaired university students, writing levels of the students and their level of knowledge about the type and structure of the text to be written were decisive in the determination of writing components. In addition, ongoing assessments before and after the education are considered an important guide for the process.

Since this study aimed to bring the students in independent writing skills by gradually giving higher levels of responsibilities, texts were written starting with Interactive Writing, and guided Writing and Independent Writing components were also used in later stages. However, the writing components to be used with a different group of hearing-impaired students must be determined in consideration of their language levels. In this study, based on the assessments for the properties of the students, the lessons were predominantly performed with Interactive Writing, which is the main subject of this paper. Interactive Writing positively affects the improvement of the writing skills of students and increases their writing motivation, since the lecturer and the students generate a text jointly, the students are supported at the time and in the amount they need in line with their actual levels and they receive immediate feedback from the lecturer.

In the study, the data for the determination of the BLIA writing component to be used and its implementation are explained and discussed. The study is limited to the examination of the improvement of seven students enrolled to the 
only School providing vocational education to hearing-impaired students in Turkey. It is thought that this paper will be used as a source by academicians and guide lecturers in planning and implementing their lessons. The research can be repeated in different educational environments, with different participants and by different researchers in a longer period of time. In addition, researches reviewing only the effectiveness of Interactive Writing can be conducted. Besides, as is understood as a result of the literature search, further studies to determine the level of the writing skills of middle school hearing-impaired students and improve their educational environments can be planned in our country.

\section{References}

Antia, S. D., Reed, S., \& Kreimeyer, K. H. (2005). Written language of deaf and hard of hearing students in public schools. Journal of Deaf Studies and Deaf Education, 10(3), 244-255. https://doi.org/10.1093/deafed/eni026

Asselin, M. (1999). Balanced literacy. Teacher Librarian, 27(1), 69-70.

Button, K., Johnson, M.J., \& Furgerson, P. (1996). Interactive writing in a primary classroom. The Reading Teacher, 49(6).

Cambra, C. (1994). An instructional program approach to improve hearing impaired adolescents' narratives: A pilot study. The Volta Review, 96(3), 237-246.

Creswell, J. W. (2005). Educational research:planning, conducting, and evaluating quantitative and qualitative research. Columbus, Upper Saddle River.

De La Paz, S., Monte-Sano, C., Arbor, A., Felton, M., Croninger, R., Jackson, C., et all. (2016). A Historical Writing for Adolescents: Integrating Disciplinary Learning With Cognitive Strategies. Reading Research Quarterly, 52(1), 31-52. https://doi.org/10.1002/rrq.147

Dostal, H., \& Gabriel, R. (2015) Interactive writing in the disciplines: A common core approach to disciplinary writing in middle and high school. The Clearing House, 88, 66-71. https://doi.org/10.1080/00098655.2015.1005036

Dostal, H., M., \& Wolbers, K. A. (2014). Developing language and writing skills of deaf and hard of hearing students: A simultaneous approach. Literacy Research and Instruction, 53, 245-268. https://doi.org/10.1080/19388071.2014.907382

Erdiken, B. (1989). Eskişehir Sağırlar Okulu ve Anadolu Üniversitesi IÇEM'de ortaokul sınıflarına devam eden 13-14 yaş işitme engelli ögrencilerin yazılı anlatım becerilerinin betimlenmesi. (Yayımlanmamış Yüksek Lisans Tezi, Anadolu Üniversitesi, Sosyal Bilimler Enstitüsü, Eskişehir, Türkiye). (Tez No. 8901)

Erdiken, B. (1996). Anadolu Üniversitesi IÇEM lise düzeyindeki işitme engelli öğrencilerin yazılı anlatım becerilerinin geliştirilmesinde işbirliği-gözlem yöntemi ile anlatım yönteminin karşılaş̧tırlması. (Yayımlanmamış doktora tezi, Anadolu Üniversitesi, Sosyal Bilimler Enstitüsü, Eskişehir, Türkiye).

Fox, B. J. (1983). Tecahing occupational vocabulary in the industrial arts classroom. Man Society Technology, 42, 6-9.

Fraenkel, J., \& Wallen, N. (2003). How to design and evaluate research in education (4th ed.). USA: McGraw-Hill.

Girgin, Ü., \& Karasu, H. P. (2007). İşitsel/Sözel Yaklaşım'la eğitim gören işitme engelli öğrencilerin yazılı anlatım becerilerinin değerlendirilmesi. Hacettepe Üniversitesi Ĕgitim Fakültesi Dergisi., 33, 146-156.

Heilman, A. W., Blair, T. R., \& Rupley, W. H. (1990). Principles and practices of teaching reading (7th ed.). New York, Merrill Prentice Hall.

Johnson, P.A. (2002). A short guide to action research. Boston, MA: Allyn and Bacon, Inc.

Joseph, N. (2006). Strategies for Success: Teaching Metacognitive Skills to Adolescent Learners. The NERA Journal, 42(1), 33-39.

Karasu, G., Girgin, Ü., Uzuner, Y., \& Kaya, Z. (2012). İşitme engelli üniversite öğrencilerine uygulanan 'tanımlama yapma' stratejisinin incelenmesi. Anadolu Journal of Educational Science International, 2(1), 19-41.

Karasu, G., Girgin, U., Uzuner, Y., \& Kaya, Z. (2016). Vocabulary developing strategies applied to individual with hearing impairments. Educational Research and Review, 11(15), 1402-1414. https://doi.org/10.5897/ERR2016.2835

Karasu, H. P. (2014). İşitme yetersizliği olan öğrencilerin yazılı ürünleri gözden geçirme ve düzeltme evresine duydukları ihtiyacın belirlenmesi. Kuram ve Uygulamada Eğitim Bilimleri, 14(3), 1089-1109.

Karasu, H. P., \& Girgin, Ü. (2007). Kaynaştırmadaki işitme engelli çocukların yazılı anlatım becerilerini değerlendi- 
rilmesi. Anadolu Üniversitesi Sosyal Bilimler Dergisi, 7(1), 467-488.

Kaya, Z. (2012). Isşitme engelli yüksekokul öğrencilerine bilgisayar yazılımı kullanımının ögretilmesi: Eylem araştırması. Yayımlanmamış doktora tezi, Anadolu Üniversitesi Eğitim Bilimleri Enstitüsü, Eskişehir, Türkiye. (Tez No.312593)

Kronenberg, E. (2014). The advantages and challenges of using interactive writing in a writers' workshop. Unpublished master dissertation, Westminster College, Salt Lake City, Utah, USA.

Luckner, J. L., \& Cooke, C. (2010). A summary of the vocabulary resarch with who are deaf or hard of hearing. American Annals of the Deaf, 155(1), 38-67. https://doi.org/10.1353/aad.0.0129

McCarrier, A., Fountas, I. C., \& Pinnell, G. S. (2000). Interactive writing: How language and literacy come together, $K-2$. Portsmouth, NH: Heinemann.

Mills, G. E. (2003). Action research a guide for the teacher researcher. United States. Upper Saddle River, N.J Merrill/Prentice Hall.

Nagy W. E., Anderson R. C., \& Herman, P. A. (1987). Learning word meaning from context during normal reading. American Educational Research Journal, Summer, 24(2), 237-270. https://doi.org/10.3102/00028312024002237

Paul, V. P. (1998). Literacy and deafness: The development of reading, writing and literate thought. Boston: Allyn and Bacon.

Pressley, M., Roehrig., A., Bogner, K., Raphael, L. M., \& Dolezal, S. (2002). Balanced literacy instruction. Focus on Exceptional Children, 34(5), 1-14.

Richards, J. C., \& Renandya, W. A. (2008). Methodology in language teaching: An anthology of current practice. Newyork: Cambridge Universtiy Press.

Rose, S., Mc Anally, P. L., \& Quigley, S. P. (2004). Language learning practices with deaf children (3rd ed.). Austin. Pro Ed.

Schirmer, B. R. (2000). Language and literacy development in children who are deaf. Boston, MA: Allyn and Bacon.

Scott-Weich, B., \& Yaden, D. B. (2017). Scaffolded writing and early literacy development with children who are deaf: A case study. Early Child Development And Care, 187(3-4), 418-435. https://doi.org/10.1080/03004430.2016.1246446

Searfoss, L. W., \& Readence, J. E. (1989). Helping children learn to read. Boston. Allyn and Bacon.

Tompkins, G. E. (2000). Teaching writing: Balancing process and product. Upper Saddle River, New Jersey. Merril Publishing Company.

Tompkins, G. E. (2007). Literacy for the 21st century, teaching reading and writing in prekindergarten throughgrade 4. New Jersey Columbus, Ohio. Merril Prentice-Hall.

Uzuner, Y. (2007). The impact of strategies used in the Blanced Literacy Approach on story grammar acquisition of three Turkish students with hearing loss: An action study. Deafness and Education International, 9(1), 24-44. https://doi.org/10.1179/146431507790560075

Williams, C. (2011). Adapted Interactive Writing Instruction with kindergarten children who are deaf or hard of hearing. American Annals of Deaf, 156(1), 23-34. https://doi.org/10.1353/aad.2011.0011

Wolbers, K. A. (2008) Using balanced and interactive writing instruction to improve the higher order and lower order writing skills of deaf students. Journal of Deaf Studies and Deaf Education, 13(2), 257-277. https://doi.org/10.1093/deafed/enm052

Wolbers, K. A., Dostal, H. M., \& Bowers, L. M. (2012). 'I was born full deaf.' Written language outcomes after 1 year of Strategic an Interactive Writing Instruction. The Journal of Deaf Studies and Deaf Education, 17(1), 19-38. https://doi.org/10.1093/deafed/enr018

Wolbers, K. A., Dostal, H. M., Graham, S., Cihak, D., Kilpatrick, J. R., \& Saulburry, R., (2015). The writing performance of elementary students receiving strategic and interactive writing instruction. Journal of Deaf Studies and Deaf Education, 20(4), 385-398. https://doi.org/10.1093/deafed/env022

Yıldırım, A., \& Şimşek, H. (2006). Sosyal bilimlerde nitel araştırma yöntemleri. Ankara, Seçkin Yayıncılık.

Yoshinaga-Itano, C., Snyder, L. S., \& Mayberry, R. (1996). How do deaf and normally hearing students convey meaning within and between written sentences. Volta Review, 98, 3-38. 
Yuknis, C. (2014). A Grounded Theory of text revision processes used by young adolescents who are deaf. Councilfor Exceptional Children, 80(3), 307-322. https://doi.org/10.1177/0014402914522426 